\title{
Lukion yleissivistys rakentuu oppiaineissa
}

Syksyllä 2019 julkaistuissa Lukion opetussuunnitelman perusteissa luonnehditaan laaja-alaista osaamista. Laaja-alainen osaaminen on herättänyt kansalaiskeskustelua: esimerkiksi Helsingin Sanomat (HS, 7.11.2019) uutisoi koko lukio-opetuksen mullistuvan kurssien muuttuessa opintopisteiksi ja oppiaineiden rajojen murtuvan nyt helpommin. Asiantuntija-arviona on esitetty (HS, 8.11.2019), että "Uusi opetussuunnitelma vähentää lukio-opintojen sirpaleisuutta, mutta rohkeampaakin uudistusta olisi kaivattu". Oppiainejakoinen lukio näyttäytyy siis sirpaleisena ja oppiaineiden välillä on muureja. Keskustelussa tuntuu unohtuvan se, että lukion oppiaineiden taustalla on tieteen- ja taiteenaloja, joissa on ajan kuluessa syntynyt vahvaa tietoa. Tämä tiedonalojen vahva tieto (Powerful disciplinary knowledge, PDK) mahdollistaa laaja-alaisen osaamisen kuvailujen mukaista toimintaa ja tätä korostetaan lukion opetussuunnitelman perusteissa muun muassa seuraavalla tavalla: "Lukion opetussuunnitelman perusteissa kuvatut oppiaineiden oppimäärät muodostavat lukiokoulutuksessa saavutettavan osaamisen perustan. Lukiokoulutuksen tehtävän mukainen yleissivistys rakentuu oppiaineissa määritellystä tiedonalakohtaisesta osaamisesta, jota laaja-alainen osaaminen tukee ja syventää" (s. 61).

Laaja-alaisen osaamisen kuvailua voidaan pitää opetussuunnitelman yleisenä ohjeena suunnata oppiaineiden opetusta sellaisiin sisältöihin, että opiskelijat pääsevät kokemaan tiedonalojen vahvaa tietoa. Mitä tämä vahva tieto on, määrittyy kunkin tieteen- tai taiteenalan sisällä. Tiedonalojen vahvan tiedon tutkimus on kansainvälisessä ainedidaktisessa tutkimuksessa nouseva tutkimusala, joka yhdistää eri aineiden opetuksen ja oppimisen tutkijoita. Toivomme, että Ainedidaktiikassa saamme jatkossa lukea, miten vahvan tiedon tutkimus auttaa opetuksen kehittämistä.

Tässä vuoden toisessa numerossa on ainedidaktiikan alan väitöstilaisuuden lection lisäksi neljä vertaisarvioitua artikkelia. Artikkelit käsittelevät monilukutaitoa, katsomuksellista yleissivistystä ja pelillisyyden mahdollisuuksia historialliseen empatiaan.

Kalle Juuti, Seija Kairavuori ja Arto Kallioniemi

Helsingin yliopisto, Kasvatustieteellinen tiedekunta 